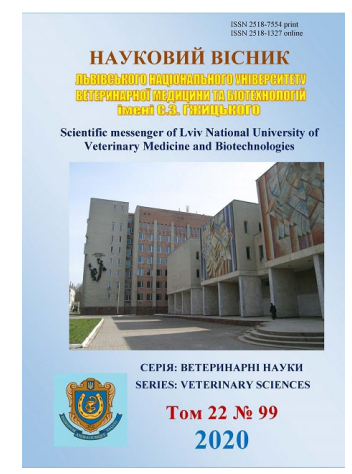

\author{
Науковий вісник Аьвівського національного університету \\ ветеринарної медицини та біотехнологій імені С.3. Гжицького. \\ Серія: Ветеринарні науки \\ Scientific Messenger of Lviv National University \\ of Veterinary Medicine and Biotechnologies. \\ Series: Veterinary sciences
}

\title{
The effectiveness of "Iodozol" in combination therapy in the treatment of postpartum vulvitis in goats
}

\author{
R. M. Sachuk ${ }^{1}$, Ya. S. Stravsky ${ }^{2}$, O. A. Katsaraba ${ }^{3}$, C. A. Ponomareva ${ }^{4}$, N. V. Ostapiv ${ }^{4}$, L. V. Kalynovska $^{4}$, \\ Ye. Ie. Kostyshyn ${ }^{3}$
}

${ }^{1}$ Rivne State University for the Humanities, Rivne, Ukraine

${ }^{2}$ I. Horbachevsky Ternopil National Medical University, Ternopil, Ukraine

${ }^{3}$ Stepan Gzhytskyi National University of Veterinary Medicine and Biotechnologies, Lviv, Ukraine

${ }^{4}$ State Scientific-Research Control Institute of Veterinary Drugs and Feed Additives, Lviv. Ukraine

Article info

Received 18.09.2020

Received in revised form 19.10.2020

Accepted 20.10.2020

Rivne State University for the Humanities, Plastova str., 29-a, Rivne, 33028, Ukraine. Tel.: +38-097-671-90-63

E-mail:sachuk.08@ukr.net

I. Horbachevsky Ternopil National Medical University, 1, Freedom Square, Ternopil, 46001, Ukraine

Stepan Gzhytskyi National University of Veterinary Medicine and Biotechnologies,

Pekarska, Str., 50, Lviv, 79010, Ukraine.

State Scientific-Research Control Institute of Veterinary Medicinal Products and Feed Additives Donetska str., 11, Lviv, 79019, Ukraine.
Sachuk, R. M., Stravsky, Ya. S., Katsaraba, O. A., Ponomareva, C. A., Ostapiv, N. V., Kalynovska, L. V., \& Kostyshyn, Ye. Ie. (2020). The effectiveness of "Iodozol" in combination therapy in the treatment of postpartum vulvitis in goats. Scientific Messenger of Lviv National University of Veterinary Medicine and Biotechnologies. Series: Veterinary sciences, 22(99), $193-197$. doi: $10.32718 /$ nvlvet9929

In the nosology of obstetric pathology of goats a special place is occupied by postpartum lesions of the genitals by pathogenic microflora, of which the lion's share are postpartum vulvitis. The aim of the study was to test a new treatment regimen for postpartum vulvitis in goats and to study the therapeutic efficacy of the drug "Iodozol", "Celexib" and "Dextrodev 50" in this pathology. Clinical and anamnestic data showed that the symptoms of postpartum vulvitis of goats were characterized by inflammatory edema, high pain, local fever, impaired tissue integrity, hematomas and discharge from the genital tract. Microbiological studies of secretions from the genitals revealed the presence of E. coli, S. aureus, less often - S. saprophyticus and E. faecalis. High resistance of microorganisms to fluoroquinolones and penicillins is noted. E. coli was sensitive to only $35.7 \%$ of antimicrobial drugs, including ceftriaxone, ceftiofur, and iodine. S. aureus is sensitive to $49.9 \%$ of antimicrobial drugs, including ceftriaxone, cephalexin, gentamicin, ceftiofur, iodine (highest sensitivity) and chlorhexidine. S. saprophyticus was insensitive to a number of antibiotics (oxytetracycline, gentamicin, etc.), except iodine. Taking into account microbiological researches the complex scheme of treatment of postpartum vulvitis at goats is developed. Evaluation of the effectiveness of complex therapy of this pathology in animals showed that treatment with "Iodozole", "Celexib" and "Dextrodev 50 " in a short time eliminates inflammatory symptoms (pain, infiltration, redness, discharge). At the end of the course of treatment in the blood was observed an increase in hemoglobin concentration by $13.7 \%$, a decrease in the number of erythrocytes by 1.7 and leukocytes by 2.2 times compared with treatment. The topical intrauterine drug "Iodozol", a non-steroidal injectable drug "Celexib", has been found to have a broad spectrum of antimicrobial activity, and is effective and safe to use. The drugs have an anti-edematous and analgesic effect, and symptomatic treatment with intravenous solution "Dextrodev 50" is a mandatory component of complex therapy and is aimed at replenishing the body with nutrients, as well as helps to neutralize and remove toxins from the body. Further research will be to study the clinical efficacy and develop regulations for the use of this scheme in vulvitis and cervicitis of other ruminants.

Key words: goat, vulvitis, blood, efficacy, drug, "Iodozol”, "Celexib”, "Dextrodev 50”.

\section{Ефективність застосування “Йодозолу" у комплексній терапії при лікуванні післяродового вульвіту у кіз}

Р. М. Сачук ${ }^{1}$, Я. С. Стравський ${ }^{2}$, О. А. Кацараба ${ }^{3}$, С. А. Пономарьова ${ }^{4}$ Н. В. Остапів ${ }^{4}$, Л. В. Калиновська ${ }^{4}$, €. Є. Костишин ${ }^{3}$ 
${ }^{1}$ Рівненський державний гуманітарний університет, м. Рівне, Украӥна

${ }^{2}$ Тернопільський національний медичний університет імені I. Я. Горбачевського, м. Тернопіль, Украӥна

${ }^{3}$ Львівський національний університет ветеринарної медицини та біотехнологій імені. С. 3. Гюицького, м. Львів, Україна

${ }^{4}$ Державний науково-дослідний контрольний інститут ветеринарних препаратів та кормових добавок, м. Львів, Украӥна

У нозології акушерської патології кіз особливе місие займають післяродові ураження статевих органів патогенною мікрофлорою, з них левову частку становлять післяродові вульвіти. Метою роботи було апробувати нову схему лікування за післяродового вульвіту у кіз та вивчити терапевтичну ефективність препарату “Йодозол”, "Целексиб” та "Декстродев 50" при даній патології. Клініко-анамнестичними даними встановлено, що симптоми післяродового вульвіту кіз характеризувалися запальним набряком, високою больовою реакцією, місиевим підвищенням температури, порушенням иілісності тканин, гематомами та виділеннями зі статевих шиляхів. Мікробіологічними дослідженнями виділень із статевих органів встановлено наявність E. coli, S. aureиs, piдme - S. saprophyticus ma E. faecalis. Відмічено високу стійкість мікроорганізмів до фторхінолонів і пеніщилінів. E. coli були чутливими лише до 35,7 \% антимікробних препаратів, зокрема до цефтріаксону, цефтіофуру, а також до йоду. S. аитеия чутливий до 49,9\% антимікробних препаратів, зокрема до иефтріаксону, иефалексину, гентаміцину, цефтіофуру, йоду (найбільша чутливість) та хлоргексидину. S. sарторhyticus виявився нечутливим до низки антибіотиків (окситетрациклін, гентаміцин і ін.), крім йоду. 3 врахуванням мікробіологічних досліджень розроблено комплексну схему лікування післяродового вульвіту у кіз. Оцінка ефективності комплексної терапії даної патології у тварин показала, що лікування “Йодозолом”, “Целексибом” та "Декстродевом 50" у короткі терміни усуває запальні симптоми (біль, інфільтрація, гіперемія, виділення). По завершенню курсу лікування у крові спостерігали збільшенням конщентраиї гемоглобіну на 13,7 \%, зменшенням кількості еритрочитів у 1,7 та лейкоцитів у 2,2 рази у порівнянні до лікування. Було встановлено, щзо місиевий внутрішньоматковий препарат “Йодозол”, ін'єкиійний нестероїдний лікарський засіб “Целексиб” мають широкий спектр антимікробної дї̈, вони є ефективними та безпечними при використанні. У комплексі препарати чинять протинабрякову та знеболюючу дію, а симптоматичне лікування розчином для внутрішньовенного застосування “Декстродев 50" є обов'язковим компонентом комплексної терапії та спрямоване на поповненням організму поживним матеріалом, а також сприяє знешкодженню та виведенню токсинів з організму. Подальші дослідження будуть полягати у вивченні клінічної ефективності та розробці регламентів застосування даної схеми при вульвітах і цервіцитах інших жуйних тварин.

Ключові слова: коза, вульвіт, кров, ефективність, препарат, “Йодозол”, “Целексиб”, “Декстродев 50”.

\section{Вступ}

У останні роки козівництво України починає відроджуватися. Проте кількість маточного поголів'я вкрай низька, а якісні характеристики місцевих порід недостатні (Hryshchenko \& Marchenko, 2016; Sklyarov \& Koshevoy, 2016). За такого стану лікування та профілактика акушерсько-гінекологічних захворювань кіз має першочергове значення. Вагітність і роди у цих тварин супроводжуються великим фізичним, нейрогуморальним та імунологічним напруженням, що викликає фізичну втому організму, зниження його резистентності, на грунті чого виникають різноманітні ускладнення, а зокрема післяродовий вульвіт (Zhuravel \& Davydenko, 2005; Yablonskyi et al., 2006; Fedorenko et al., 2017) Несвоєчасне лікування тварини у післяродовий період викликає неплідність, що завдає значних збитків господарствам (Sysoyev, 1978, Yablonskyi et al., 2006; Sklyarov, 2015).

Часто завадами терапії вульвіту є занижені показники імунітету кіз у післяродовий період та резистентність патогенної флори до широковживаних антибактеріальних препаратів. Окремі препарати мають обмеження, щодо застосування у період лактації, отже $\epsilon$ потреба розробляти і впроваджувати нові, дієві та безпечніші схеми лікування захворювань на основі лікарських засобів, що мають протимікробну, протизапальну та відновлюючу дію.

3 огляду на фізіологічний стан тварин при даному захворюванні, безпечнішим буде місцеве застосування йодовмісних препаратів, що мають широкий спектр протимікробної та протигрибкової дії. До того ж у доступній літературі відсутні дані про здатність йодних засобів викликати резистентність у мікроорганізмів за зовнішнього застосування. Особливо зручним є використання препарату "Йодозол" у формі аерозолю. Крім того при розробці схеми лікування враховували, те що нестероїдні протизапальні препарати за рахунок вияву широкого фармакологічного впливу на організм тварин (анальгетичний, протизапальний, антитоксичний, жарознижуючий) мають значний потенціал використання для лікування післяродової патології у кіз. 3 огляду на той факт, що при післяродовому вульвіті у кіз відзначаються морфологічні і функціональні поразки ураження окремих систем організму, детоксикація $є$ неодмінним комплексом терапії.

Тому, патогенетична терапія за комплексного лікування кіз, хворих на післяродовий вульвіт, у першу чергу направлена на зменшення запалення та зниження детоксикації.

Мета роботи - апробувати нову схему лікування за післяродового вульвіту у кіз та вивчити терапевтичну ефективність препарату “Йодозол”, “Целексиб” та “Декстродев 50” при даній патології.

\section{Матеріал і методи досліджень}

Досліди проводились у міні-фермі особистого селянського господарства Сістука В.П. с. Річиця Гощанського району Рівненської області на козах зааненскої породи віком 2-4 роки, живою масою 40-45 кг, які утримуються за стійлово-пасовищною системою, у яких діагностували клінічні форми післяродового вульвіту. 
Для вивчення терапевтичної ефективності “Йодозолу" та “Целексибу" було відібрано 7 тварин, у яких діагностували післяродовий вульвіт. Тваринам вводили внутрішньоматково засіб “Йодозол" та ін'єкційно препарат “Целексиб”. “Йодозол” попередньо перед введенням підігрівали до температури +35 $40^{\circ} \mathrm{C}$ і ретельно збовтували. Препарат вводили двохразово внутрішньоматково в дозі 25 мл на тварину кожні 48 годин. Препарат “Целексиб” вводили дворазово внутрішньом'язово у дозі у дозі 1 мл на 50 кг маси тіла 3 інтервалом 48 годин. Паралельно для підтримки енергетичних ресурсів і фізіологічного напруження організму кіз внутрішньовенно вводили “Декстродев 50” 100 мл на добу, поступово зі швидкістю біля 20-50 мл/хв, протягом 3 діб.

Препарат “Йодозол” містить йод і калію йодид. Дія лікарського засобу “Йодозол” обумовлюється 3 тривалим виділенням молекулярного йоду. Дає сильний окислювальний ефект, руйнує органічні речовини, частково окислюючи та замінюючи їх. Присутність органічних речовин зменшує його бактерицидну дію. Йодид калію сприяє розчиненню йоду і запобігає появі йодидної кислоти та ії солей. Утворенням піни надає можливість впливу активної речовини на всю внутрішню поверхню стінки матки та іiі роги. Після нанесення на слизову оболонку статевих органів, діючі речовини незначно всмоктуються у системний кровоток. Йод виводиться з організму через нирки і в меншій мірі через шлунково-кишковий тракт, легені і шкіру.

“Целексиб” - нестероїдний протизапальний препарат $з$ вираженою болезаспокійливою та жарознижуючою дією у якості діючої речовини целекоксиб. Целекоксиб являється синтетична сполука 3 класу нестроїдних протизапальних речовин, що належать до інгібіторів циклооксигенази-2 (COX-2), які мають знеболюючі, жарознижуючі, протизапальні властивості. Механізм дії целекоксибу полягає у селективному інгібуванні СОХ-2 - ключового ферменту синтезу медіаторів запалення. Внаслідок високої селективності дії, целекоксиб не спричиняє побічні ефекти, що властиві іншим нестероїдним протизапальним препаратам (утворення виразок травного каналу, порушення ниркового кровотоку, геморагічні явища). "Целексиб" є безпечним у застосуванні, може використовуватися під час вагітності та в період лактації, оскільки доведено відсутність тератогенного ефекту (Silverstein et al., 2000). Діюча речовина препарату після ін'єкції швидко проникає у тканини, де знаходиться тривалий час.

Розчин для внутрішньовенного застосування “Декстродев 50” містить діючу речовину декстроза. Після внутрішньовенного введення гіпертонічного розчину декстрози підвищується осмолярність крові, стимулюються процеси обміну речовин, покращується детоксикаційна функція печінки, посилюється скоротлива функція міокарду, збільшується діурез. У процесі метаболізму декстрози у тканинах утворюється значна кількість енергії, яка необхідна для життєдіяльності організму. Лікарські засоби “Йодозол”, “Це- лексиб” та “Декстродев 50” проходять передреєстраційні клінічні випробування.

При клінічному обстеженні піддослідних кіз користувалися загальноприйнятими методами. Оцінювали загальний стан тварин, запальний набряк, больову реакцію, місцеве підвищення температури, порушення цілісності тканин і гематоми.

Мікробіологічні дослідження проводили у лабораторії мікробіології рівненської регіональної лабораторії ветеринарної медицини згідно з загальноприйнятими методиками. Для дослідження мікрофлори зразки досліджуваного матеріалу висівали на поживні середовища. При цьому використовували для виділення стафілококів - BD Baird-Parker Agar (HiMedia, Індія); коліформних бактерій - агар Ендо (Фармактив, Україна), ентерококів - Ентерокок агар (Фармактив, Україна). Культивування проводили за температури $37^{\circ} \mathrm{C}$, результати оцінювали через 24-48 годин. Ідентифікацію чистих культур проводили за морфологічними, тинкторіальними, культуральними, біохімічними властивостями, які описані у визначнику бактерій Берджі (Vos et al., 2011).

Чутливість ізолятів до антибактеріальних препаратів визначали диско-дифузійним методом, використовуючи диски 3 антибіотиками (Himedia, Індія). При постановці методу використовували Mueller Hinton Agar (Himedia, Індія). Приготування мікробних суспензій проводили відповідно до оптичного стандарту мутності 1,0 одиниць за шкалою McFarland з використанням приладу Densi-LaMeter (PLIVA-Lachema Diagnostika, Чехія).

Визначення чутливості мікроорганізмів до препаратів проводили таким способом. Готували суспензії 3 чистих культур, висівали суспензії в чашки Петрі 3 відповідним середовищем, виготовляли в середовищі лунки за допомогою пробійника № 10, заповнювали їх експериментальними зразками лікарських засобів. Чашки Петрі інкубували в термостаті упродовж 24 годин, потім оцінювали результат за діаметром затримання росту мікроорганізмів навколо лунки. Діаметр до 15 мм - мікроорганізми нечутливі до антисептиків, від 16 до 20 мм - мікроорганізми помірно чутливі до антисептиків, від 21 до 25 мм - мікроорганізми чутливі до антисептиків, від 26 мм і більше мікроорганізми високочутливі до антисептиків.

Морфологічні дослідження крові кіз проводили до та після лікування. Кількість еритроцитів та лейкоцитів визначали в камері Горяєва, вміст гемоглобіну за допомогою гемометра. Дослідження крові також проводили на автоматичному гематологічному аналізатоpi "РCЕ-170" у лабораторії з контролю якості, безпечності та реєстрації ветеринарних лікарських засобів і кормових добавок ТОВ “ДЕВІЕ” (Chumachenko et al., 1990, Vlizlo, et al., 2012).

Статистичну обробку результатів проводили за загальноприйнятою біометричною методикою (Rokytskyy P.F. 1973). Різницю між двома середніми величинами вважали статистично вірогідною при ${ }^{*}-\mathrm{P}<0,05 ;{ }^{* *}-\mathrm{P}<0,01 ;{ }^{* * *}-\mathrm{P}<0,001$. 


\section{Результати та їх обговорення}

При зборі анамнезу встановлено, що травми м'яких тканин $є$ наслідком важких і патологічних родів у кіз з послідуючим інфікуванням патогенною мікрофлорою. Клінічні симптоми післяродового вульвіту характеризувалися запальним набряком, високою больовою реакцією, місцевим підвищенням температури, порушення цілісності тканин, гематомами, виділення (рис. 1).

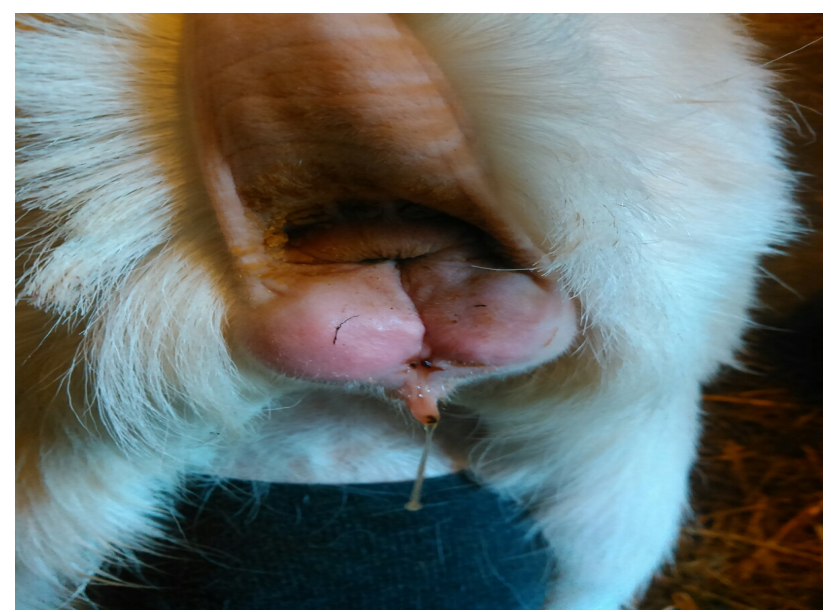

Рис. 1. Клінічна картина вульвіту у кіз

3 виділень виділяли E. coli, S. aureus, рідше S. saprophyticus ma E. faecalis. Щодо резистентності виділеної флори, відмічено високу стійкість мікроорганізмів до фторхінолонів і пеніцилінів. Так, культури
E. coli були чутливими лише до 35,7 \% антимікробних препаратів, зокрема до цефтріаксону, цефтіофуру, а також до йоду. $S$. aureus чутливий до 49,9 \% антимікробних препаратів, зокрема до цефтріаксону, цефалексину, гентаміцину, цефтіофуру, йоду (найбільша чутливість) та хлоргексидину. Тоді як, S. saprophyticus виявився нечутливим до низки антибіотиків (окситетрациклін, гентаміцин і ін.), крім йоду.

За отриманими мікробіологічними результатами у комплексне лікування післяродового вульвіту кіз було включено препарат “Йодозол” у формі аерозолю.

Оцінка ефективності комплексної терапії післяродового вульвіту у кіз показала, що лікування “Йодозолом" у короткі терміни усуває запальні симптоми (біль, інфільтрація, гіперемія, виділення). До переваг застосування внутрішньоматкового препарату слід віднести й зручну форму випуску - аерозоль 3 катетером, який забезпечує рівномірне, повне і щадне зрошення вульви. Як наслідок уже на другу добу лікування загоюються мікротравми, тріщини, розриви слизової оболонки піхви та вульви та поліпшується загальний стан тварин.

Застосована нами схема комплексної терапії “Йодозолом" з ін'єкціями нестероїдного препарату “Целексиб" та метаболічного засобу “Декстродев 50" дала швидке одужання, яке гематологічно характеризувалося збільшенням концентрації гемоглобіну у крові на 13,7 \%, зменшенням кількості еритроцитів у 1,7 та лейкоцитів у 2,2 рази, а отже, мало потужніший вплив на наслідки інфекції (табл. 1).

Таблиця 1

Вплив препарату “Йодозол” на клінічні показники крові у кіз при післяродовому вульвіті, $\mathrm{M} \pm \mathrm{m}, \mathrm{n}=7$

\begin{tabular}{ccc}
\hline Показник & До лікування & Після лікування \\
\hline Гемоглобін (НB), г/л & $99,4 \pm 0,37$ & $113,0 \pm 1,67^{* * *}$ \\
Еритроцити (RBS), т/л & $18,7 \pm 0,99$ & $11,3 \pm 0,14^{* * *}$ \\
Тромбоцити (PLT), г/л & $371,5 \pm 20,77$ & $442,9 \pm 18,2^{* *}$ \\
Лейкоцити (WBS), г/л & $19,0 \pm 0,29$ & $8,7 \pm 0,23^{* * *}$ \\
Базофіли & Лейкограма, \% & - \\
Еозинофіли & - & $1,7 \pm 0,34$ \\
Юні нейтрофіли & $3,1 \pm 0,9$ & - \\
Паличкоядерні нейтрофіли & - & $1,0 \pm 0,24$ \\
Сегментоядерні нейтрофіли & $1,9 \pm 0,37$ & $47,6 \pm 0,66$ \\
Лімфоцити & $46,0 \pm 1,2$ & $47,4 \pm 0,57$ \\
Моноцити & $45,7 \pm 1,5$ & $3,6 \pm 0,88$ \\
\hline
\end{tabular}

Примітка: ${ }^{*}-\mathrm{P}<0,05 ;{ }^{* *}-\mathrm{P}<0,01 ;{ }^{* * *}-\mathrm{P}<0,001$

“Целексиб” відноситься до класу нестероїдних протизапальних препаратів з антибактеріальною дією. Він ефективно вплинув на симптоми запалення, при цьому швидко усунув біль та запалення. Препарат чинить протинабрякову та знеболюючу дію.

Отже, місцевий внутрішньоматковий препарат “Йодозол”, ін’єкційний нестероїдний лікарський засіб “Целексиб” мають широкий спектр антимікробної дії, вони $є$ ефективними та безпечними при використанні. У комплексі препарати чинять протинабрякову та знеболюючу дію, а симптоматичне лікування розчи- ном для внутрішньовенного застосування “Декстродев 50" є обов'язковим компонентом комплексної терапії та спрямоване на поповненням організму поживним матеріалом, а також сприяє знешкодженню та виведенню токсинів з організму.

\section{Висновки}

Таким чином, ефективність лікування післяродового вульвіту у кіз у першу чергу залежить від точності клінічної діагностики та встановлення причин їх 
виникнення, а також раціонального застосування лікарських засобів "Йодозол", “Целексиб” та “Декстродев 50”. Комплексна терапія зменшує інтенсивність симптомів патологічного процесу, швидко нормалізує клінічні, гематологічні показники. Результати досліджень включено до реєстраційних досьє на розроблені препарати.

Подальші дослідження будуть полягати у вивченні клінічної ефективності та розробці регламентів застосування даної схеми при вульвітах і цервіцитах інших жуйних тварин.

\section{References}

Chumachenko, V. Ye., Vysotskiy, A. M., Serdyuk, N. A., \& Chumachenko, V. V. (1990). Opredeleniye yestestvennoy rezistentnosti i obmena veshchestv $u$ sel'skokhozyaysvennykh zhivotnykh [Determination of natural resistance and metabolism in farm animals] Kyyiv: Urozhay (in Ukrainian).

Fedorenko, S., Skliarov, P., \& Koshevoy, V. (2017). Efficiency of therapy of cows and goat with hypogonadism for use of nanopreparation "Caplaestrol + OV". Scientific Messenger of LNU of Veterinary Medicine and Biotechnologies. Series: Veterinary Sciences, 19(82), 192-195. URL: https://nvlvet.com.ua/index.php/journal/article/view/1364.

Hryshchenko, N. P., \& Marchenko, I. O. (2016). Rozvytok haluzi kozivnytstva Ukrainy v umovakh yevrointehratsii [Development of the goat breeding industry of Ukraine in the conditions of European integration] Naukovyi visnyk Natsionalnoho universytetu bioresursiv i pryrodokorystuvannia Ukrainy. Seriia: Tekhnolohiia vyrobnytstva i pererobky produktsii tvarynnytstva, 236, 23-29. URL: http://journals.nubip.edu.ua/index.php/Tekhnologiya/a rticle/view/7949 (in Ukrainian).

Levchenko, V. I., Sokoliuk, V. M., Bezukh, V. M. et al. (2002) Doslidzhennia krovi tvaryn ta klinichna interpretatsiia otrymanykh rezultativ: [Animal blood tests and clinical interpretation of the results]: Metodychni rekomendatsii dlia studentiv fakultetu veterynarnoi medytsyny kerivnykiv ta slukhachiv Instytutu pisliadyplomnoho navchannia kerivnykiv i spetsialistiv veterynarnoi medytsyny. Bila Tserkva (in Ukrainian).
Rokytskyy, P. F. (1973). Byolohycheskaya statistika [Biological Statistics]. Minsk: Vyshejshaja shkola (in Russian).

Silverstein, F. E., Faich, G., Goldstein, J. L. et al. (2000) Gastrointestinal toxicity with celecoxib vs nonsteroidal antiinflammatory drugs for osteoarthritis and rheumatoid arthritis. The CLASS study: a randomized controlled trial. JAMA, 284(10), 1247-1255. doi: 10.1001/jama.284.10.1247.

Sklyarov, P. M. (2015). Retinoldeficient infertility sheep and goats: pharmacological correction and prevention. Scientific Messenger of LNU of Veterinary Medicine and Biotechnologies. Series: Veterinary Sciences, 17(1), 164-170. URL: https://nvlvet.com.ua/index. php/journal/article/view/239.

Sklyarov, P., \& Koshevoy, V. (2016). Complex drugs based on nanobiomaterials, future use in the reproduction of sheep and goats. Scientific Messenger of LNU of Veterinary Medicine and Biotechnologies. Series: Veterinary Sciences, 18(2(66), 162-165. doi: 10.15421/nvlvet6633.

Sysoyev, A. A. (1978) Fiziologiya razmnozheniya sel'skokhozyaystvennykh zhivotnykh [Physiology of reproduction of farm animals] M.: Kolos (in Russian).

Vlizlo, V. V., Fedoruk, R. S., Ratych, I. B. et. al. (2012) Laboratorni metody doslidzhen' u biolohiyi, tvarynnytstvi ta veterynarniy medytsyni [Laboratory methods of research in biology, livestock and veterinary medicine] L'viv: SPOLOM (in Ukrainian).

Vos, P., Garrity, G., Jones, D., Krieg, N. R., Ludwig, W., Rainey, F. A., \& Whitman, W. (2011). Bergey's Manual of Systematic Bacteriology: Volume 3: The Firmicutes (Vol. 3). Springer Science \& Business Media. URL: https://www.springer.com/gp/book/9780387950419.

Yablonskyi, V. A., Khomyn, S. P., Kalynovskyi, H. M., Kharuta, H. H., Kharenko, M. I., \& Zaviriukha, V. I. (2006) Veterynarne akusherstvo, hinekolohiia ta biotekhnolohiia vidtvorennia tvaryn $\mathrm{z}$ osnovamy androlohii [Veterinary obstetrics, gynecology and biotechnology of reproduction of animals with the basics of andrology]. Vinnytsia: Nova Knyha (in Ukrainian).

Zhuravel, M. P., \& Davydenko, V. M. (2005). Tekhnolohiia vidtvorennia silskohospodarskykh tvaryn [Technology of reproduction of agricultural animals] Slovo (in Ukrainian). 